\title{
Protective antibody response of Balb/c mice to Bali rabies virus isolate propagated in BHK-21 cells
}

\author{
I Nyoman Mantik ASTAWA ${ }^{1) *}$, Ni Luh Putu AGUSTINI'2), ( Wayan MASA TENAYA ${ }^{2)}$ \\ and I Putu Gede Widnyana ARYAWIGUNA ${ }^{3)}$
}

\author{
1)Laboratory of Veterinary Virology, Faculty of Veterinary Medicine, Udayana University, Jln. PB Sudirman, \\ Denpasar, Bali, Indonesia \\ 2)Biotechnology Laboratory, Animal Disease Investigation Center, Regional IV. Denpasar Bali, Indonesia \\ 3) Undergraduate Student at the Faculty of Veterinary Medicine, Udayana University, Jln. PB Sudirman, \\ Denpasar, Bali, Indonesia
}

\section{J. Vet. Med. Sci. \\ 80(10): 1596-1603, 2018}

doi: 10.1292/jvms.17-0385

Received: 12 July 2017

Accepted: 20 August 2018

Published online in J-STAGE:

11 September 2018

\begin{abstract}
The protective antibody response of Balb/c mice to Bali rabies virus (RABV) in BHK-21 cells was studied. The virus was isolated from a rabid dog and was adapted to replicate in BHK-21 cell culture for seven passages. The BHK-21-adapted Bali RABV (BHK-Bali RABV) was inactivated with binary ethylenimine and 24 mice were immunized twice at 21-days intervals with the inactivated virus and Rabisin ${ }^{\circledR}$ vaccine. Virus replication was detected using indirect immunofluorescence, immunocytochemistry, and western blotting assays. Enzyme-linked immunosorbent assay examination 2 weeks after the first immunization revealed RABV antibody titers that were mostly below the minimum protective level $(<0.5$ equivalent unit, EU). Antibody titers increased sharply after the second immunization. Antibody titers in serum of mice induced by inactivated BHK-Bali RABV one week after the second immunization were slightly lower (0.8-3.8 EU) than those induced by Rabisin vaccine (0.9-6.3 EU). RABV antibody titers were stable for at least 6 weeks after the second immunization. Both Rabisin vaccine and inactivated BHK-Bali RABV induced neutralizing antibodies with neutralization titers (50\% protective dose per $\mathrm{m} /$ ) of $2^{9.84}$ for $0.1 \mathrm{~m} /$ Rabisin, $2^{11.41}$ for $0.2 \mathrm{~m} /$ Rabisin, $2^{7.41}$ for $0.1 \mathrm{~m} / \mathrm{BHK}$-Bali RABV, and $2^{8.25}$ for $0.2 \mathrm{~m} /$ BHK-Bali RABV. Thus, inactivated BHK-Bali RABV induces a protective immune response in Balb/c mice, but at lower levels compared to induction by Rabisin vaccine.
\end{abstract}

KEY WORDS: antibody, Bali rabies virus isolate, BHK-21, mice, protective antibody response

Rabies is an important zoonotic viral disease caused by lyssavirus of the Rhabdoviridae family. In Indonesia, the disease is still endemic in 24 of 33 provinces including Bali [18, 23]. In Bali, the first rabies outbreak occurred in 2008, after which mass vaccination was carried out to cover more than $70 \%$ of the canine population. However, human and animal deaths caused by the bites of rabid dogs are still reported in Bali [27]. Several rabies vaccines from different producers have been used to vaccinate dogs and other animals, but the disease still cannot be eradicated from Bali. An isolate of rabies virus (RABV) from a rabid dog in Bali was demonstrated to replicate very well in BHK-21 cell culture using indirect immunofluorescence assay (IIFA), immunocytochemistry (ICC), and western blotting (WB) assay. The virus is thus a candidate for development of a rabies vaccine for animals.

Generally, RABV replicates in many cell lines including BHK-21 and Vero cells [7, 21, 22, 31], without producing any observable cytopathic effect (CPE) [22]. The replication of the virus in many types of cell cultures has enabled the mass production of RABV for use in the preparation of antigens for diagnostic and vaccine purposes. Recently, the RABV used in the preparation of vaccine for both animals and human has also been propagated in cell cultures, including Vero cells (generally for human vaccines) $[10,33]$ and BHK-21 cells (generally for animal vaccines) [11,35]. However, RABV used for vaccine production generally belongs to fixed RABV strains, such as the Pasteur strain (PV) isolated in 1882 [9, 28], Street Alabama Dufferin (SAD), Pitman Moore (PM) $[9,32]$, and others. The genetic differences between fixed RABV strains used in the preparation of vaccine and the field RABV strains may have implications for the effectiveness of current RABV vaccines [20]. Thus, the use of local RABV isolate as a vaccine candidate is likely to improve the effectiveness of rabies vaccine in preventing the disease in susceptible hosts, especially when the isolate replicates efficiently in cell culture producing high titer of virus released into the medium of infected cells.

*Correspondence to: Astawa, I N. M.: mantik.astawa@unud.ac.id

O2018 The Japanese Society of Veterinary Science

This is an open-access article distributed under the terms of the Creative Commons Attribution Non-Commercial No Derivatives (by-nc-nd) License. (CC-BY-NC-ND 4.0: https://creativecommons.org/licenses/by-nc-nd/4.o/) 
Rabies virus consists of a single-stranded RNA genome that encodes five major structural proteins: N (nucleocapsid), $\mathrm{P}$ (phosphoprotein), M (matrix protein), G (glycoprotein), and L (replicase) [8, 34]. RABV glycoprotein is important in the induction of neutralizing antibodies, which are the major indicator of protective immunity against RABV in susceptible hosts. Antibodies that bind with RABV glycoprotein, especially when they bind with the epitopes at the receptor-binding sites of the protein, block the attachment of the virus to the host cells $[13,17]$, preventing infection. The use of a local RABV isolate to immunize animals might be advantageous in terms of its extensive homology to the local street RABV, especially concerning the glycoprotein gene. However, the nucleotide sequence of the Bali RABV glycoprotein gene has not been determined.

BLAST analysis using the data available at Genbank has revealed $98.7 \%$ glycoprotein amino acid sequence identity between two Indonesian RABV isolates, strain 03003INDO (accession EU086151) [4] and strain SNO1-23 (accession AB115921). The glycoprotein amino acid sequence identity between these two Indonesian RABV isolates and the RABV Pasteur strain (accession P08667) [29] is 91.4 and 91.6\% respectively. Thus, the level of glycoprotein amino acid sequence identity among Indonesian RABV isolates is higher than those between the Indonesian RABV isolates and the RABV Pasteur strain. The latter is the virus strain used in the preparation of the Rabisin ${ }^{\circledR}$ vaccine (Merial, Lyon, France).

We have examined the growth characteristics of Bali RABV isolate in BHK-21 cells and the ability of the inactivated virus to induce protective immune response in mice. As comparison, the Rabisin vaccine was used as a positive control. This vaccine is used to vaccinate dogs and other animals in Indonesia and induces a protective immune response in experimental dogs [6].

\section{MATERIALS AND METHODS}

\section{Ethical approval}

The use of mice was approved by The Ethical Commission for the Use of Animals in Research and Education, Faculty of Veterinary Medicine, Udayana University, Bali, Indonesia (Ethical Clearance No. 283/KE-PH/H/2017).

\section{Virus and cell cultures}

The Bali RABV isolate was obtained from Animal Disease Investigation Center Denpasar, Bali, Indonesia. The virus was isolated from a rabid dog and had been previously confirmed using direct IFA (dIFA) and mouse inoculation test (unpublished data). The virus was then adapted to replicate in BHK-21 cell culture for seven passages. Briefly, the brain homogenate of the rabid dog was prepared in a sterile tube, sterile-filtered using a $0.2 \mu \mathrm{m}$ syringe filter, and inoculated into a monolayer of BHK-21 cells. The virus was passaged seven times. The presence of RABV antigen in the medium and cells of the BHK-21 cell culture was detected after the passages 3-7 by IIFA, ICC, and WB.

\section{Antibodies}

Monoclonal antibodies (mAbs) against RABV were produced by fusion of myeloma cells with spleen lymphocytes (spleenocytes) of mice immunized with the Rabisin vaccine [3]. Sera collected from mice sacrificed for the preparation of antirabies $\mathrm{mAbs}$ were used as the source of polyclonal antibody (pAb).

\section{Detection of Bali rabies virus replication in BHK-21 cells}

The replication of Bali RABV isolate in BHK-21 cells was detected by IIFA and ICC. IIFA was performed by a standard method using mAb against RABV. Briefly, BHK-21 cells were grown in 24-well tissue culture plates until they reached $80 \%$ confluence and then were inoculated with the medium of infected BHK-21 cells. Following 3 days incubation at $37^{\circ} \mathrm{C}$ in a $5 \%$ $\mathrm{CO}_{2}$ environment, RABV-infected cells were trypsinized and washed three times with phosphate buffered saline (PBS). A smear of RABV-infected BHK-21 cells was prepared on poly-L-lysine-coated microscope slides, air dried, and fixed with cold acetone for $10 \mathrm{~min}$ at room temperature. Anti-RABV mAb diluted 1:2 in PBS was added and incubated for 30 min at room temperature. After three washes with PBS, anti-mouse IgG conjugated with fluorescein isothiocyanate (Sigma-Aldrich, St. Louis, MO, U.S.A.) was added and incubated for $30 \mathrm{~min}$ at room temperature. Following three washes as above, the cells were mounted with $90 \%$ buffered glycerin and covered with a cover slip. The presence of viral antigen in the infected cells was examined by ultraviolet microscopy.

ICC was used to detect RABV-infected BHK-21 cells in 96- or 24-well tissue culture plates. The infected cells were fixed with $80 \%$ cold acetone at $-20^{\circ} \mathrm{C}$ for 10 min. Following two washes with PBS, anti-RABV mAb was added and incubated for 30 min at room temperature. After three washes with PBS, Histofine ${ }^{\circledR}$ Simple stain Max Po (Multi) universal immune-peroxidase anti-rabbit/ mouse (Nichirei Bioscience Inc., Tokyo, Japan) was added and incubated for $30 \mathrm{~min}$ at room temperature. Diaminobenzidine (DAB) substrate (Nichirei Bioscience Inc.) was then added and incubated for 5 min at room temperature. The substrate reaction was stopped by washing the cells with tap water. For safety, the ICC-stained BHK-21 cells were kept in 10\% buffered formaldehyde and the presence of infected cells was determined by inverted microscope (Primo Vert, Zeiss Microscopy, Now York, NY, U.S.A.) with low to high magnification $(40 \times$ to $200 \times)$. The presence of infected cells were also examined under conventional light microscope (Olympus CX-21, Tokyo, Japan) by counterstaining with Mayer's hematoxylin and cutting the bottom of 24 well tissue culture wells containing RABV-infected BHK-21 cells stained with ICC technique. The cut was then mounted on microscope slides and examined under light microscope.

The presences of RABV proteins in BHK-21 cell lysate, in culture medium, and in the Rabisin vaccine samples was detected by WB. Samples of medium and cells of RABV-infected BHK-21 cell culture, and Rabisin vaccine samples were subjected to sodium dodecyl sulfate-polyacrylamide gel electrophoresis [14]. The separated proteins were transferred to nitrocellulose membrane for 2 hr in 
a wet tank mini transblot system (Bio-Rad, Hercules, CA, U.S.A.) using a previously described carbonate-bicarbonate transfer buffer system [5]. The presence of RABV proteins was visualized by adding anti-RABV mAb and pAb as previously described [3].

\section{Titration of virus}

Virus titrations were conducted to determine the amount of RABV released into the medium of RABV-infected BHK-21 cells. The virus titers were determined using a quantitative assay to determine tissue culture dose $50\left(\mathrm{TCID}_{50}\right)$ and ICC to determine focus forming units (FFUs). Briefly, serial ten-fold dilutions of virus stock (BHK-21-infected cell culture medium) were prepared in sterile serum-free DMEM (Dulbecco's Modified Eagle's Medium). In a quantitative assay to determine TCID $_{50}, 50-\mu l$ samples from each dilution were inoculated into five wells of 96-well tissue culture plates. One hundred microliters of BHK-21 cells (approximately $10^{5}$ cells per $\mathrm{m} l$ suspended in DMEM containing 10\% fetal bovine serum, FBS) were added to each wells and incubated for 2 days at $37^{\circ} \mathrm{C}$ in a humid atmosphere containing $5 \% \mathrm{CO}_{2}$. The infected cells were stained using the ICC technique described above and were examined using the aforementioned inverted microscope at a high magnification $(200 \times)$. The virus titer was calculated by the Reed and Muench method $[24,25]$. To determine FFU, samples from each dilution were inoculated in duplicate $(0.1 \mathrm{~m} l$ per well) in $24-$ well tissue culture plates containing a confluent monolayer of BHK-21 cell culture. After incubation for $1 \mathrm{hr}$ at $37^{\circ} \mathrm{C}$ the inoculum was removed and the cells were covered with semisolid DMEM (DMEM containing 1\% agarose, 5\% FBS, and gentamycin). Following 3 days incubation at $37^{\circ} \mathrm{C}$ in the humid $5 \% \mathrm{CO}_{2}$ environment the semisolid medium was removed and the infected cells were stained using the aforementioned ICC technique. The numbers of foci were examined in each well using the aforementioned inverted microscope at low magnification $(40 \times)$. Virus titers were calculated by multiplying the dilution factor and number of foci observed in wells of 24-well tissue culture plates containing RABV-infected cells.

\section{Preparation of inactivated rabies virus for immunization of mice}

Rabies virus used for immunization of mice was inactivated with 2-bromoethylamine hydrobromide (Sigma-Aldrich) as previously described [16]. The compound was dissolved in $0.5 \mathrm{M}$ sodium hydroxide $(\mathrm{NaOH})$ at the concentration of $0.6 \mathrm{M}$ and was converted to binary ethylenimine (BEI) by incubation at $37^{\circ} \mathrm{C}$ for $1 \mathrm{hr}$. The BEI was then added to the virus stock at a final concentration of $0.03 \mathrm{M}$, incubated for $18 \mathrm{hr}$ at $37^{\circ} \mathrm{C}$, and neutralized by adding sodium thiosulfate (Sigma-Aldrich) to a final concentration of $2 \%$. The inactivated virus was then mixed thoroughly with aluminum hydroxide adjuvant (60\% virus: 40\% adjuvant).

\section{Immunization of mice}

Twenty four 7-8 week-old mice (12 females and 12 males) were divided into four treatment groups according to the type and dose of immunogen: Rabisin vaccine either 0.1 or $0.2 \mathrm{~m} l$ per mouse; BHK-21-adapted Bali RABV isolate either 0.1 or $0.2 \mathrm{~m} l$ per mouse. Each treatment group consisted of six mice (three females and three males) were immunized twice at a 21-day interval. Sera samples were collected four times in 2 weeks after the first immunization and 1, 2, and 6 weeks after the second immunization.

\section{ELISA for mouse immune response to rabies virus}

Antibody titers against RABV in sera samples of mice were examined by indirect ELISA using a commercial rabies ELISA kit (PUSVETMA, Surabaya, Indonesia) as described by the manufacturer [26]. One hundred microliters of mice sera samples (each diluted 1:200) were added to wells of a RABV-coated ELISA plate and incubated for $1 \mathrm{hr}$ at $37^{\circ} \mathrm{C}$. The plate was washed three times with PBS-T and $100 \mu \mathrm{l}$ of protein A horseradish peroxidase (1:16,000 dilution) was added and incubated for $1 \mathrm{hr}$ at $37^{\circ} \mathrm{C}$. Following three washes with PBS-T, 2,2'-azino bis (3 ethylbenzothiazoline-6-sulfonic acid) was added to each well and incubated for $10 \mathrm{~min}$ at room temperature. The reaction was stopped using stop solution. The optical density of substrate in each well was read using an ELISA reader with a 405-nm filter. The antibody titers were calculated using 3-parameters logistic regression and were expressed as equivalent units (EUs) as described by the manufacturer [26].

\section{Neutralization assay}

ICC-based serum neutralization test was carried out to determine the neutralizing activities of antibodies in sera samples collected 1 week after the second immunization. Sera samples were grouped and pooled according to treatment groups, and were then tested by ELISA as described above. Serial 2-fold dilutions of pooled mice sera were prepared in serum-free DMEM and sera samples from each dilution were distributed into five wells (50 $\mu \mathrm{l}$ per well) of 96-well tissue culture plates. Fifty microliters BHKBali RABV suspended in serum-free DMEM containing approximately 100 tissue culture infectious doses $\left(\mathrm{TCID}_{50}\right)$ was added to each well and incubated for $90 \mathrm{~min}$ at $37^{\circ} \mathrm{C}$. Fifty microliters of trypsinized BHK-21 cells $\left(2 \times 10^{5}\right.$ cells per $\left.\mathrm{m} l\right)$ suspended in DMEM containing $15 \%$ FBS were added to each well and incubated for 2 days at $37^{\circ} \mathrm{C}$ in a $5 \% \mathrm{CO}_{2}$ environment. The infected and uninfected cells were stained using the ICC technique as described above and were examined using an inverted microscope at high magnification $(200 \times)$. Wells with uninfected and infected BHK-21 cells were counted. The neutralization titers of antibody in sera samples were calculated using the Reed and Muench formula and were expressed as protective doses $50\left(\mathrm{PD}_{50}\right)$ [24, 25].

\section{RESULTS}

Growth characteristics of Bali rabies virus isolate in BHK-21 cells

IIFA revealed that the Bali RABV isolate replicated very well in BHK-21 cells (Fig. 1A). No RABV antigen was detected by 

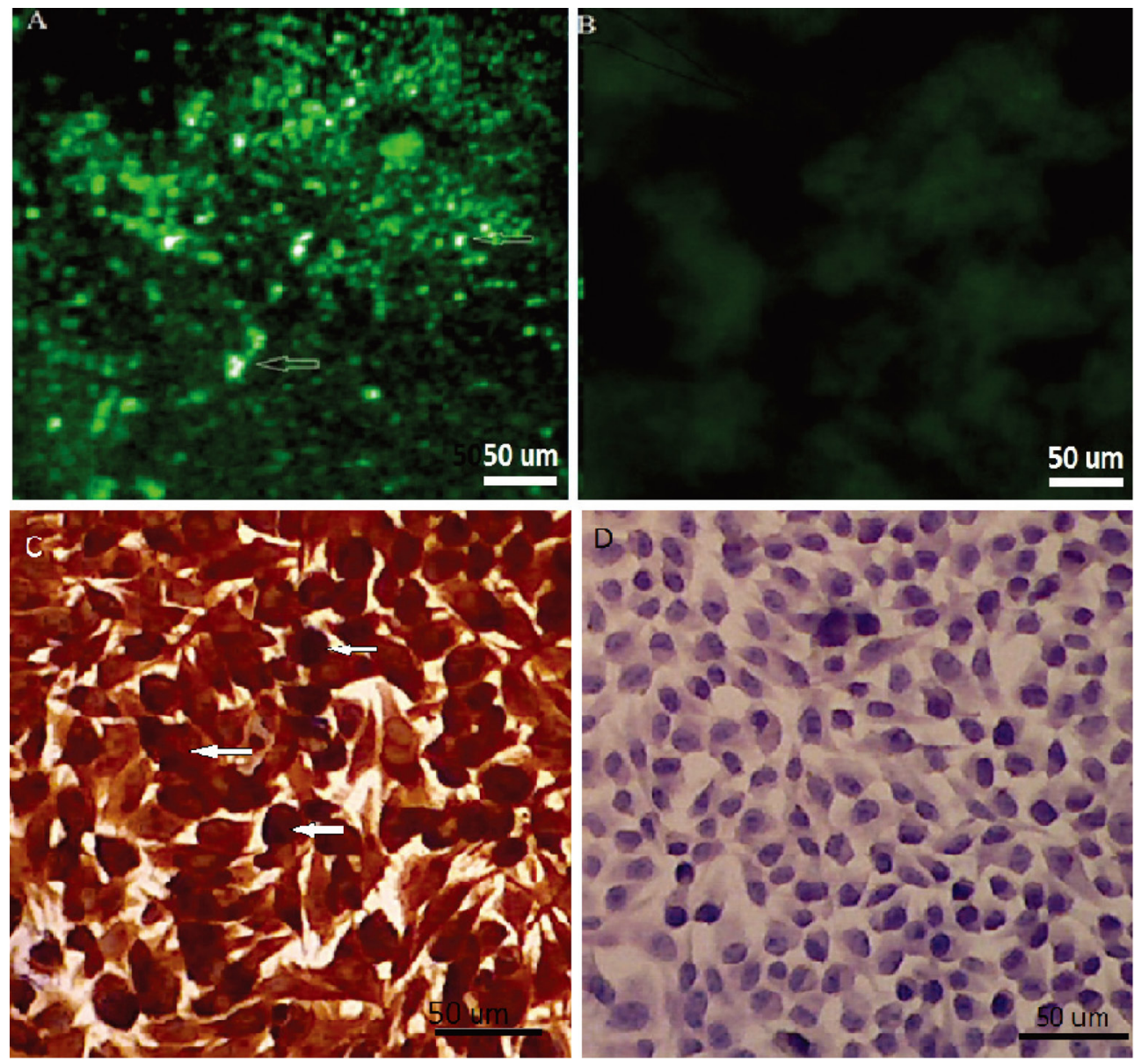

Fig. 1. Detection of rabies virus antigen using indirect immunofluorescence assay (IIFA) and immunocytochemistry (ICC) assay in infected BHK-21 cell cultures. Infected cells (A and C) and uninfected cells (B and D). The infected cells (arrows) are apparent as bright yellowish-green fluorescence (in IIFA) and as brown cells with violet nuclei (in the ICC assay).

IIFA in normal uninfected BHK-21 cells (Fig. 1B). RABV antigen was consistently detected by IIFA in infected BHK-21 cell cultures from the third to seventh passages. Similarly, RABV antigen was also detected by the ICC technique in BHK-21 cells infected with Bali RABV isolate (Fig. 1C), but not in uninfected cells (Fig. 1D). No CPE was observed in BHK-21 cells infected with Bali RABV isolate (data not shown).

The presence of RABV in both medium and cells of infected BHK-21 cell culture was also detected by WB using pAb and $\mathrm{mAb}$. RABV proteins were detected in the medium in fresh and inactivated samples, and in the lysate of infected BHK-21 cells. RABV proteins were also detected in Rabisin vaccine samples. Rabies virus protein was not detected in the medium and cell lysate of uninfected BHK-21 cell cultures (Fig. 2). At least three RABV protein bands ranging from 38 to $56 \mathrm{kDa}$ were detected by WB in the media of BHK-21 infected cells and Rabisin vaccine samples using anti-RABV mAb and pAb. Lysates from infected BHK21 cells displayed many additional protein bands detected by WB using both mAb and pAb (Fig. 2).

Titration of the Bali RABV isolate in the medium of infected BHK-21 cells after the third to the seventh passages also showed consistent results. The titers of the RABV in the medium of infected cells increased slightly after each passage following four serial passages (passages 3-7). The virus titer after the third passage was $10^{4.62} \mathrm{TCID}_{50}$ per $\mathrm{ml}$ medium and increased to $10^{5.83} \mathrm{TCID}_{50}$ per $\mathrm{m} l$ after the seventh passage. In this quantitative assay, the infected and uninfected cells were evident as brown cells (Fig. 3A) and unstained cells (Fig. 3B), respectively. Titration of RABV with the focus assay after seven passages also showed a similar result. The titer of virus released into the medium of infected cells was $8.2 \times 10^{5} \mathrm{FFU}$ per $\mathrm{m} l$ medium (Table 1 ). Infected and uninfected cells were evident in the focus assay as brown foci surrounded by unstained cells (Fig. 3C) and as unstained cells (Fig. 3D), respectively.

\section{Antibody response of mice against BHK-21 adapted rabies virus}

ELISA showed that the antibody titers against RABV in sera samples collected 2 weeks after the first immunization were mostly below the minimum protective levels $(<0.5 \mathrm{EU})$. Only nine $(37 \%)$ of 24 sera samples displayed antibody titers $>0.5 \mathrm{EU}$ per $\mathrm{m} l$. The antibody titers increased sharply at 1 week after the second immunization (1.9 to $4.52 \mathrm{EU}$ ). The antibody titers then declined slightly at 2 weeks (1.55 to $2.35 \mathrm{EU}$ ) and 6 weeks (1.1 to $1.32 \mathrm{EU}$ ) after the second immunization (Fig. 4A).

The doses of immunogens also affected the immune response of mice against RABV. At 2 weeks after the first immunization 


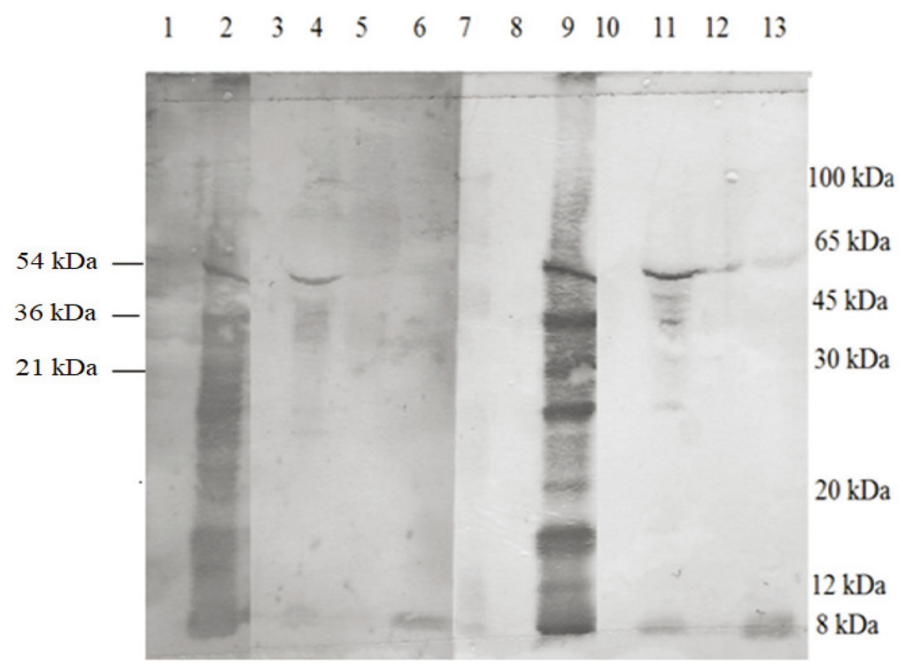

Fig. 2. Western blot analysis of Bali rabies virus isolate propagated in baby hamster kidney-21 (BHK-21) cell culture and Rabisin vaccine. Antigens: 1 and 8 (uninfected BHK-21 cells), 2 and 9: (infected BHK-21 cells), 3 and 10: (uninfected BHK-21 cell culture medium), lanes 4 and 11 (fresh infected BHK-21 cell culture medium), lanes 5 and 12: (infected BHK-21 medium inactivated with binary ethylenimine), lanes 6 and 13: (Rabisin vaccine) and lane 7. Prestained standard markers. Antibodies: lanes 1-6 detected with polyclonal antibodies. Lanes 8-13 detected with monoclonal antibody.

with $0.1 \mathrm{~m} l$ of immunogen, the antibody titers against RABV were slightly lower than those immunized with $0.2 \mathrm{~m} l$ immunogen. However, 1, 2, and 6 weeks after the second immunization, antibody titers induced by immunization with $0.2 \mathrm{~m} l$ immunogen per mouse were consistently higher than those induced by $0.1 \mathrm{ml}$ immunogen per mouse (Fig. 4B).

\section{Neutralizing activity of antibodies}

The titers of neutralizing antibodies against Bali RABV in sera samples of mice immunized with inactivated BHK-21-Bali RABV and Rabisin vaccine were measured only at 1 week after the second immunization. ELISA revealed titers of anti-RABV antibodies in the groups of pooled sera samples were 3.3 EU (Rabisin 0.1 ml), 4.1 EU (Rabisin 0.2 ml), 2.9 EU (BHK-Bali RABV $0.1 \mathrm{~m} l$ ), and 4.3 EU (BHK-Bali RABV $0.2 \mathrm{ml}$ ). The titers of neutralizing antibodies induced by BHK-Bali RABV $\left(2^{7.41} \mathrm{PD}_{50}\right.$ and $2^{8.25} \mathrm{PD}_{50}$ for doses of 0.1 and $0.2 \mathrm{ml}$, respectively) were generally lower than those induced by Rabisin vaccine $\left(2^{9.84} \mathrm{PD}_{50}\right.$ and $2^{11.16} \mathrm{PD}_{50}$ for doses of 0.1 and $0.2 \mathrm{ml}$, respectively) (Table 2).

\section{DISCUSSION}

In susceptible hosts, RABV is a primary neurotrophic virus that infects neurons in both the central and peripheral nervous systems [30]. In cell cultures, however, RABV can infect many types of cells, including those of non-neural origins, such as BHK21 cells $[1,12,21]$ and Vero cells [33]. A local RABV isolated from a rabid dog in Bali also replicated very well in BHK-21 cells. The titers of the virus released into the medium of BHK-21 infected cells tended to increase following each passage (Table 1). Replication of the Bali RABV isolate in BHK-21 cells was further confirmed by the presence of viral antigen at high level in the infected cells as detected by IIFA (Fig. 1A) and ICC (Fig. 1B), without an observable CPE. The result was similar to the previous finding that RABV infections can persist for prolonged periods in cell cultures without causing an observable CPE [22]. The use of simple and rapid detection methods such as IIFA and ICC is important to detect RABV infection in BHK-21 cells following inoculation with the Bali RABV isolate (Fig. 1A). The availability of a good anti-RABV mAb is also important. Such a mAb has been produced [3] and has been used as a ligand for affinity chromatography purification of RABV proteins from the brains of infected dogs and mice [2].

The presence of RABV antigen in both medium and cells of BHK-21 cell culture infected with the Bali RABV isolate and in Rabisin vaccine samples were also detected by WB using both mAb and pAb. In the media of infected BHK-21 cells and in Rabisin vaccine, only one to three protein bands with molecular weights ranging from 38 to $56 \mathrm{kDa}$ were detected. In infected cell lysates, however, multiple protein bands were detected using both $\mathrm{mAb}$ and $\mathrm{pAb}$. It is not yet known why the viral protein bands detected in infected BHK-21 cells were multiple bands consisting of more than five bands. Rabies virus particles consist of five major structural proteins designated L (200 kDa), G (65 kDa), N (54 kDa), P (36 kDa), and M (21 kDa) [8, 34]. However, no protein band was detected in the medium and cells of uninfected BHK-21 cells. Thus, the protein bands detected by WB in the infected BHK-21 cell culture were confirmed as RABV proteins.

Although the replication of Bali RABV isolate in BHK-21 cells did not cause any observable change in the morphology of cells, the infected cells constantly released infectious virus into the medium of the infected cells [31]. Virus titration conducted after each passage from the third to seventh passages showed that the titer of virus in the media of infected cells increased slightly following each 

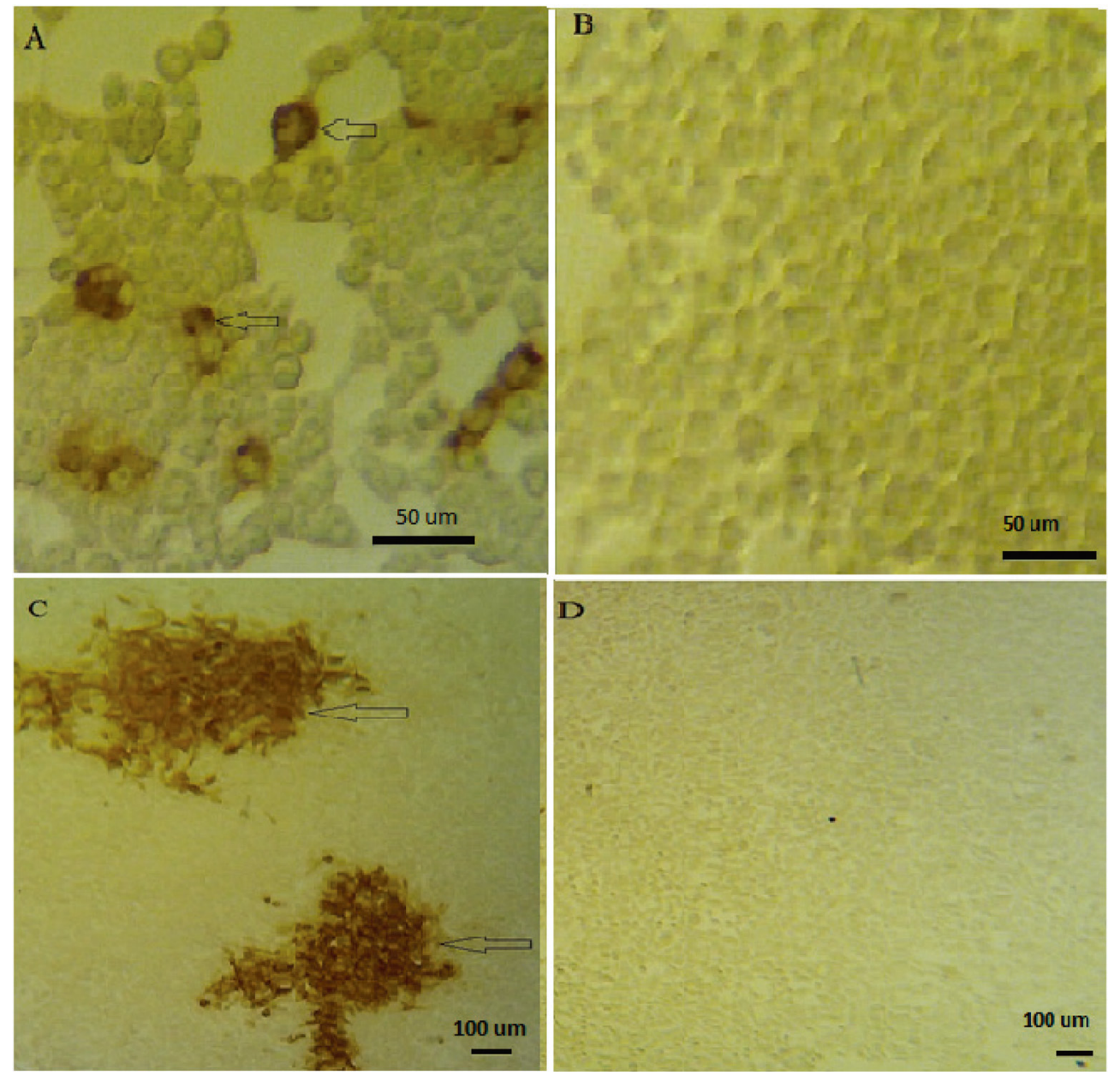

Fig. 3. Detection of rabies virus antigen by immunocytochemistry assay to visualize the infected and uninfected cells following titration procedures. Quantitative assay to determine $\operatorname{TCID}_{50}(\mathrm{~A}$ and B) and ICC to determine focus forming units (FFU) (C and D). The infected and uninfected cells are shown, respectively, as cells with dark brown cells (arrow), and unstained cytoplasm.

passage. This indicates that passages increase the replication efficiency of Bali RABV isolate in BHK-21 cell culture [1]. Further passages of Bali RABV isolate in BHK-21 cells are required to achieve virus titers adequate for preparation of rabies vaccine.

Antibody responses of mice against inactivated BHK-Bali RABV antigen were comparable to those induced by the commercial Rabisin vaccine, which is currently being used for the immunization of dogs and other animals in Indonesia, including Bali. The levels of antibody responses following the first immunization were generally low and below the minimum protective level ( $>0.5 \mathrm{EU})$. Only a few mice displayed antibody titers exceeding 0.5 EU. However, following the second immunization, antibody responses induced by both BHK-Bali RABV isolate and Rabisin vaccine were $>0.5 \mathrm{EU}$, which is the minimum protective level of anti-RABV antibody in serum as described by the ELISA kit manufacturer [26]. The highest antibody levels induced by both BHK-21-adapted RABV of Bali isolate and Rabisin vaccine were observed 1 week after the second immunization and declined slightly at 2 and 6 weeks after the second immunization. Rabisin vaccine is one of many commercially available rabies vaccines being used for vaccination of animals in Indonesia. Experimental studies in dogs showed that this vaccine induces a good antibody response in dogs [6]. Thus, it was used as the positive control in this study. The doses of the BHK-Bali RABV and Rabisin vaccine immunogens also affected the immune responses of mice against RABV. For both immunogens, doses of $0.2 \mathrm{~m} l$ per mouse induced higher antibody responses than those induced by $0.1 \mathrm{~m} l$ per mouse.

Observations of antibody titers in mice sera up to 6 weeks following the second immunization showed that the immune responses induced by BHK-Bali RABV and Rabisin vaccine in mice were stable for at least 6 weeks following the second 
A

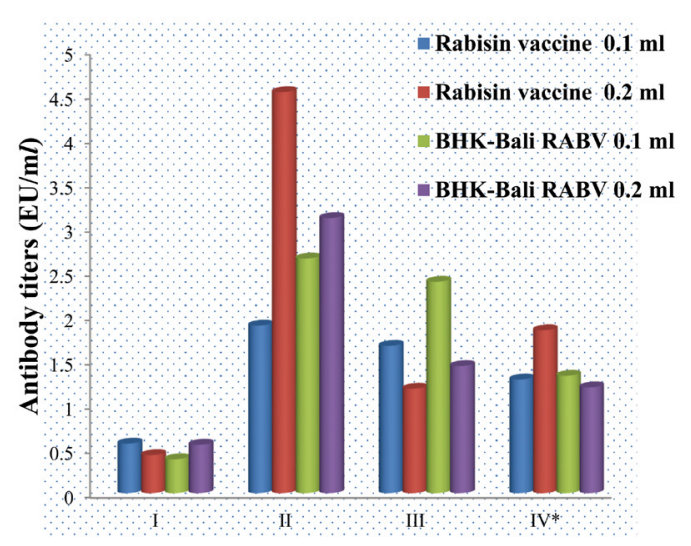

B

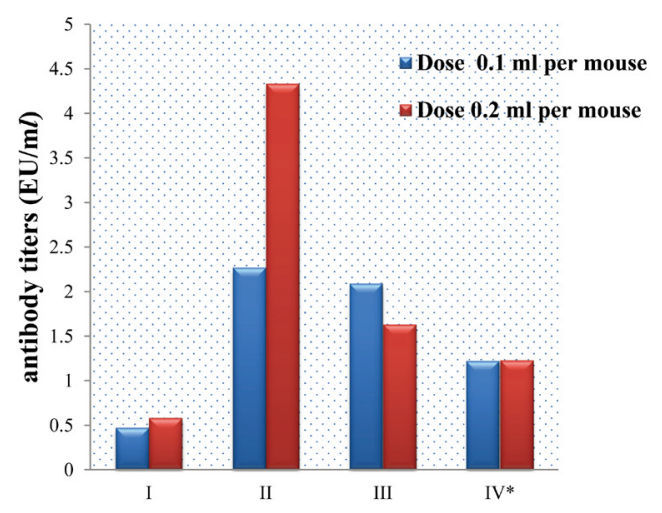

Fig. 4. Antibody titers against RABV in mice sera according to treatment groups of immunogens and doses, after imunization of mice with inactivated BHK-Bali RABV isolate and Rabisin vaccine. Combination of immunogen and doses (A) and the dose of immunogens (B). * Times after immunizations at which the antibody titers in mice sera were measured by ELISA, i.e., at 2 weeks after the first immunization (I), and at 1 week (II), 2 weeks (III), and 6 weeks (IV) after the second immunization.

Table 2. ELISA and neutralization titers of antibodies in pooled sera samples according to immunogens and doses treatment groups

\begin{tabular}{lccc}
\hline \multicolumn{1}{c}{ Immunogens } & Doses $(\mathrm{m} l)$ & ELISA titers $(\mathrm{EU} / \mathrm{m} l)$ & Neutralization titers $\left(\mathrm{PD}_{50} / \mathrm{m} l\right)$ \\
\hline Rabisin Vaccine & 0.1 & 3.3 & $2^{9.84}$ \\
Rabisin Vaccine & 0.2 & 4.1 & $2^{11.16}$ \\
BHK-Bali RABV & 0.1 & 2.9 & $2^{7.41}$ \\
BHK- Bali RABV & 0.2 & 4.3 & $2^{8.25}$ \\
\hline
\end{tabular}

ELISA: enzyme-linked immunosorbent assay, EU: equivalent units, $\mathrm{PD}_{50}$ : protective dose 50.

immunization. In addition, the stability of immune response induced by $0.2 \mathrm{ml}$ immunogen per mouse was slightly better than those induced by $0.1 \mathrm{ml}$ immunogen per mouse. Stability of immune response induced by RABV antigen is one of many requirements for the preparation of rabies vaccine. For this reason, further passages of Bali RABV isolate in BHK-21 cells are still required to increase the replication efficiency, which in turn, will increase the titers of virus released into the medium of infected cells. In previous studies, further passages increased the RABV titers in cell cultures $[1,15]$.

Neutralizing antibodies are the major indicator of protective immune responses against viral infection in hosts after vaccination or natural infection as their presence can inhibit infection by blocking the attachment of virus to its receptor on susceptible cells. In this study, although neutralizing antibodies were not examined according to the procedure described by the Organization for Animal Health [19] and were measured only 1 week following the second immunization, the results showed that inactivated BHKBali RABV was able to induce neutralizing antibodies in mice. However, the titer of neutralizing antibody induced by BHK-Bali RABV was still significantly lower than those induced by the Rabisin vaccine (Table 2). The result was unexpected as the ELISA results showed that the titers of antibody against RABV in a pooled sera of mice immunized with BHK-Bali RABV and the Rabisin vaccine were not significantly different (Table 2). The discrepancy between the antibody titers measured by ELISA and the neutralization assay is probably due to the differences in the purity of virus used in the Rabisin vaccine and in BHK-Bali RABV. In this study, no purification step was carried out in the preparation of BHK-Bali RABV used for the immunization of mice. Nevertheless, the ability of inactivated BHK-Bali RABV to induce antibody response with neutralizing activities clearly shows that this local Bali RABV isolate is able to induce protective immune response in mice. The higher levels of glycoprotein amino acid sequence identity among Indonesian RABV isolates than those between Indonesian RABV isolates and RABV vaccine strains appear to be one advantage of using local RABV isolate as a vaccine candidate.

A higher titer of virus is still needed to achieve a better protective immune response in the immunized animals. In addition to higher passages in BHK-21 cell culture [1, 15], other approaches, such as the use of roller culture system [10] and modification of cell culture media [7, 10], can also be adopted to increase the titer of RABV propagated in cell culture. When higher titers are achieved, a more comprehensive study using dogs as experimental animal will be necessary.

ACKNOWLEDGMENTS. The study was partly supported by the Ministry of Research and Technology, and Higher Education, Republic of Indonesia under the research scheme of "Hibah Bersaing". This study was partly conducted at the Animal Disease Investigation Centre (DIC), Denpasar, Bali, Indonesia. We thank the Director of DIC for providing facilities that enabled us to carry out this study. 


\section{REFERENCES}

1. Aga, A. M., Hurisa, B., Tesfaye, T., Lemma, H., Niguse, D., G/Wold, G., Kebede, A., Mesele, T. and Urga, K. 2014. Adaptation of local rabies virus isolates to high growth titer and determination of pathogenicity to develop canine vaccine in Ethiopia. J. Vaccines Vaccin. 5: 245 doi: $10.4172 / 2157-7560.1000245$.

2. Astawa, N. M., Kencana, G. A. Y. and Suardana, I. B. K. 2016. Monoclonal antibodies as ligands for purification of RV proteins from brain tissues of dogs and mice. J. Vet. 17: 556-563.

3. Astawa, N. M., Suardana, I. B. K. and Kencana, G. A. Y. 2015. Produksi dan karakterisasi antibodi monoklonal anti-glikoprotein virus rabies. Prosiding Seminar Nasional Sain dan Teknologi 2015: 1177-1183.

4. Bourhy, H., Reynes, J. M., Dunham, E. J., Dacheux, L., Larrous, F., Huong, V. T. Q., Xu, G., Yan, J., Miranda, M. E. and Holmes, E. C. 2008. The origin and phylogeography of dog rabies virus. J. Gen. Virol. 89: 2673-2681. [Medline] [CrossRef]

5. Dunn, S. D. 1986. Effects of the modification of transfer buffer composition and the renaturation of proteins in gels on the recognition of proteins on Western blots by monoclonal antibodies. Anal. Biochem. 157: 144-153. [Medline] [CrossRef]

6. Faiziah, Astawa, N. M., Putra, A. A. G. and Suwarno. 2012. The humoral immune response of dogs vaccinated with oral SAG2 and parenteral with Rabisin and Rabivet Supra92. Indon. J. Biomed. Sci. 6: 26-29.

7. Frazatti-Gallina, N. M., Mourão-Fuches, R. M., Paoli, R. L., Silva, M. L. N., Miyaki, C., Valentini, E. J. G., Raw, I. and Higashi, H. G. 2004. Verocell rabies vaccine produced using serum-free medium. Vaccine 23: 511-517. [Medline] [CrossRef]

8. Gupta, A. K., Blondel, D., Choudhary, S. and Banerjee, A. K. 2000. The phosphoprotein of rabies virus is phosphorylated by a unique cellular protein kinase and specific isomers of protein kinase C. J. Virol. 74: 91-98. [Medline] [CrossRef]

9. Hicks, D. J., Fooks, A. R. and Johnson, N. 2012. Developments in rabies vaccines. Clin. Exp. Immunol. 169: 199-204. [Medline] [CrossRef]

10. Hurisaa, B., Mengeshaa, A., Newayesilassiea, B., Kergaa, S., Kebedea, G., Bankoviskyb, D., Metlinc, A. and Urgaa, K. 2013. Production of cell culture based anti- rabies vaccine in Ethiopia. Procedia Vaccinol. 7: 2-7. [CrossRef]

11. Kallel, H., Rourou, S., Majoul, S. and Loukil, H. 2003. A novel process for the production of a veterinary rabies vaccine in BHK-21 cells grown on microcarriers in a 20-1 bioreactor. Appl. Microbiol. Biotechnol. 61: 441-446. [Medline] [CrossRef]

12. Kanitz, F. A., Cargnelutti, J. F., Weiblen, R., Batista, H. B. C. R. and Flores, E. F. 2015. Virus isolation in cell culture for confirmatory diagnostic of rabies in bovine specimens. Cienc. Rural 45: 2193-2196. [CrossRef]

13. Kuzmina, N. A., Kuzmin, I. V., Ellison, J. A. and Rupprecht, C. E. 2013. Conservation of binding epitopes for monoclonal antibodies on the rabies virus glycoprotein. J. Antivir. Antiretrovir. 5: 37-43.

14. Laemmli, U. K. 1970. Cleavage of structural proteins during the assembly of the head of bacteriophage T4. Nature 227: 680-685. [Medline] [CrossRef]

15. Liu, Y., Zhang, S., Zhang, F. and Hu, R. 2012. Adaptation of a Chinese ferret badger strain of rabies virus to high-titered growth in BHK-21 cells for canine vaccine development. Arch. Virol. 157: 2397-2403. [Medline] [CrossRef]

16. Mondal, S. K., Neelima, M., Reddy, K. S. R., Rao, K. A. and Srinivasan, V. A. 2005. Validation of the inactivant binary ethylenimine for inactivating rabies virus for veterinary rabies vaccine production. Biologicals 33: 185-189. [Medline]

17. Mori, T. and Morimoto, K. 2014. Rabies virus glycoprotein variants display different patterns in rabies monosynaptic tracing. Front. Neuroanat. 7: 47. [CrossRef] [Medline]

18. Nasution, K. 2012. Is it possible to eliminate rabies in Indonesia? J. Indon. Med. Assoc. 62: 165-168.

19. OIE (World Organization for Animal Health). 2013. Rabies. pp. 1-28. In: OIE-Terrestrial Manual.

20. Orłowska, A. and Żmudziński, J. F. 2015. Genetic characterisation of the rabies virus vaccine strains used for oral immunization of foxes in Poland to estimate the effectiveness of vaccination. Arch. Virol. 160: 509-515. [Medline] [CrossRef]

21. Paldurai, A., Singh, R. P., Gupta, P. K., Sharma, B. and Pandey, K. D. 2014. Growth Kinetics of Rabies Virus in BHK-21 Cells using fluorescent activated cell sorter (FACS) analysis and a monoclonal antibody based cell-ELISA. J. Immunol. Vaccine Technol. 1: 103.

22. Patel, A. C., Upmanyu, V., Ramasamy, S., Gupta, P. K., Singh, R. and Singh, R. P. 2015. Molecular and immunogenic characterization of BHK-21 cell line adapted CVS-11 strain of rabies virus and future prospect in vaccination strategy. Virusdisease 26: 288-296. [Medline] [CrossRef]

23. Putra, A. A. G., Hampson, K., Girardi, J., Hiby, E., Knobel, D., Mardiana, I. W., Townsend, S. and Scott-Orr, H. 2013. Response to a rabies epidemic, Bali, Indonesia, 2008-2011. Emerg. Infect. Dis. 19: 648-651. [Medline] [CrossRef]

24. Ramakrishnan, M. A. 2016. Determination of 50\% endpoint titer using a simple formula. World J. Virol. 5: 85-86. [Medline] [CrossRef]

25. Reed, L. J. and Muench, H. 1938. A simple methods of estimating fifty percent endpoints. Am. J. Hyg. 27: 493-497.

26. Saputri, P. N., Estikoma, D. and Sholichah, N. 2012. Kit ELISA Rabies PUSVETMA. http://www.affaveti.org/wp-content/uploads/2015/02/ PRESENTASI-ILMIAH-21.pdf [accessed on July 12, 2017].

27. Setiaji, G. and Agustini, N. L. P. 2011. Kajian respons antibody rabies pada anjing pasca vaksinasi di pulau Bali (Serosurvey of Rabies Antibody Response in Vaccinated Dogs in Bali Island). Bul. Vet. 23: 36-44.

28. Smith, K. 2012. Louis Pasteur, the father of immunology? Front. Immunol. 3: 68. [Medline] [CrossRef]

29. Tordo, N., Poch, O., Ermine, A., Keith, G. and Rougeon, F. 1986. Walking along the rabies genome: is the large G-L intergenic region a remnant gene? Proc. Natl. Acad. Sci. U.S.A. 83: 3914-3918. [Medline] [CrossRef]

30. Tsiang, H., Koulakoff, A., Bizzini, B. and Berwald-Netter, Y. 1983. Neurotropism of rabies virus. An in vitro study. J. Neuropathol. Exp. Neurol. 42: 439-452. [Medline] [CrossRef]

31. Wild, T. F. and Bijlenga, G. 1981. A rabies virus persistent infection in BHK21 cells. J. Gen. Virol. 57: 169-177. [Medline] [CrossRef]

32. Wunderli, P. S., Dreesen, D. W., Miller, T. J. and Baer, G. M. 2003. Effect of heterogeneity of rabies virus strain and challenge route on efficacy of inactivated rabies vaccines in mice. Am. J. Vet. Res. 64: 499-505. [Medline] [CrossRef]

33. Yu, P., Huang, Y., Zhang, Y., Tang, Q. and Liang, G. 2012. Production and evaluation of a chromatographically purified Vero cell rabies vaccine (PVRV) in China using microcarrier technology. Hum. Vaccin. Immunother. 8: 1230-1235. [Medline] [CrossRef]

34. Zaides, V. M., Krotova, L. I., Selimova, L. M., Selimov, M. A., Elbert, L. B. and Zhdanov, V. M. 1979. Reevaluation of the proteins in rabies virus particles. J. Virol. 29: 1226-1228. [Medline]

35. Zavareh, Z. 2000. Immunogenicity of BHK-Rabies vaccine in Cattle. Iranian Biomed. J. 4: 129-131. 